Case Report

\title{
Citizen Coproduction and Social Media Communication: Delivering a Municipal Government's Urban Services through Digital Participation
}

\author{
Wonhyuk Cho *(D) and Winda Dwi Melisa
}

Wellington School of Business and Government, Victoria University of Wellington, Wellington 6011, New Zealand; winda.melisa@penerjemahpemerintah.id

* Correspondence: wonhyuk.cho@vuw.ac.nz

check for updates

Citation: Cho, Wonhyuk, and Winda Dwi Melisa. 2021. Citizen

Coproduction and Social Media Communication: Delivering a Municipal Government's Urban Services through Digital Participation. Administrative Sciences 11: 59. https://doi.org/10.3390/ admsci11020059

Received: 2 April 2021

Accepted: 8 June 2021

Published: 15 June 2021

Publisher's Note: MDPI stays neutral with regard to jurisdictional claims in published maps and institutional affiliations.

Copyright: (c) 2021 by the authors. Licensee MDPI, Basel, Switzerland. This article is an open access article distributed under the terms and conditions of the Creative Commons Attribution (CC BY) license (https:// creativecommons.org/licenses/by/ $4.0 /)$.

\begin{abstract}
This study investigated how social media is used by a municipal government agency for communication of citizen coproduction initiatives, through social media content analysis of the government's official Twitter account. This article identified that the dominant form of social media coproduction in the Bandung municipal government in Indonesia is government-to-citizen (G2C) interaction, focused primarily on informing and nudging (86.62\%) citizens, as well as some limited elements of citizen-to-government $(\mathrm{C} 2 \mathrm{G})$ communication, such as citizen sourcing and citizen reporting (8.96\%). The municipal government uses various visual tools on Twitter to disseminate G2C information and convey its messages. Regarding the phase of the service cycle, this study found that the majority of social media communications are related to co-assessment (52.26\%) and co-designing (42.24\%), with a limited number of tweets about co-delivery (3.25\%). Based on these findings, this article discusses the shifting relationship between government and citizens brought on by the adoption of this social media platform in its service delivery arrangement.
\end{abstract}

Keywords: social media; local government; coproduction; twitter; public service

\section{Introduction}

The increasing complexity of socioeconomic problems and budget constraints caused by the "new fiscal ice age" has encouraged governments to adjust the ways in which public services are produced and delivered (Gazley et al. 2020; Kiewiet and McCubbins 2014). Joshi and Moore (2004) suggested that both the monopolistic provision of public services and the New Public Management (NPM) model regarding citizens as customers are perceived as old-fashioned-in response, governments have encouraged citizens to engage in various supporting activities for public services (Gazley et al. 2020; Sievert 2021). Bovaird (2007) identified coproduction as an alternative process in which public agencies are no longer the sole producer of public services, but rather the coproducer, with various partners. Citizens are expected to help governments produce services, as one of the public agencies' partners under the user-driven service model (Fotaki 2011; McGann et al. 2021). Ostrom (1996) and Pestoff (2006) pointed out that coproduction entails a change of relationship between government and citizens, as citizens become willing to, or are expected to, play an active role in the production of public services.

The concept of coproduction describes the service delivery process in which citizens are directly involved via professional agents (Brudney and England 1983; McMullin 2021). Ostrom (1996) broadly defined coproduction as occurring when the production process of public goods and services involves inputs from citizens. Joshi and Moore (2004) defined it more narrowly, as "institutionalized coproduction," an organizational arrangement in which service users take part in service delivery in a "routine" manner. Liu (2021) focused more on the "crowdsourcing" (or "citizen-sourcing") aspect of citizen coproduction in policy design and service implementation. The recent literature has begun to identify 
various aspects of coproduction; one trending research area examines ways of enabling voluntary citizen participation (Andersen et al. 2020; Hong 2016) and reducing associated psychological costs experienced by citizens asked to coproduce public services (Thomsen et al. 2020).

Social media and digital technologies are seen as important enablers (Alam 2020; Daneshvar et al. 2018; Venugopalan et al. 2021), allowing real-time interactions between government and citizens with almost no cost (Meijer 2011). The capacity of new media, a new form of connection between government and citizens, allows new practices of coproduction. However, evidence of these coproduction strategies has been mixed or inclusive (Kang and Van Ryzin 2019), and the characteristics of social-media-aided coproduction have been under-studied empirically.

This article analyzes the promotion and implementation of coproduction in the new media environment in an Indonesian municipal government. Coproduction through social media is generally regarded as a toolbox for citizens to contribute information for public services; more work is needed to understand its implementation beyond the passive opportunity for public participation (Dipoppa and Grossman 2020; Edelmann and Mergel 2021). This research aims to examine how the adoption of Twitter by a local government agency in Indonesia (Dinas Bina Marga dan Pengairan Kota Bandung. hereafter DBMP) promotes citizen coproduction. This research asks the following questions: What types of citizen coproduction are observed in a municipal government's social media platform? To what extent does the adoption of Twitter leverage two-way communication between government and citizens regarding citizen coproduction with the municipal government?

This study employs content analysis of social media to illustrate its use by the Indonesian municipal government. It describes the background of the local government, in Bandung in general and in DBMP Bandung more specifically, and synthesizes previous studies concerning the adoption of social media by the government and the concept and typology of coproduction. Municipal government cases in developing countries have not been well reported in the coproduction literature; therefore, this article is expected to aid in our understanding of this phenomenon, as it has diffused from the so-called Western world to developing economies.

\section{Literature Review}

\subsection{Understanding Coproduction: Concept, Theories, and Typologies}

Traditionally, citizen participation was considered an opportunity to influence policy formulation, not to help execute public programs (Mattson 1986; Whitaker 1980). Coproduction was first introduced in public administration in the late 1970s and early 1980s as a concept to help understand the role of citizens in public service production (Ostrom 1996; Parks et al. 1981; Nabatchi et al. 2017). Fiscal cutbacks in the United States created the context for its emergence in order to help develop alternative public service arrangements to (co)produce "more with less"; similar cost reduction efforts were popular in the 1990s under NPM reforms (Alford 2002). The logic of market-oriented citizen involvement was that service users can help improve service quality or reduce its cost.

The popularity of the coproduction concept waned in the 1990s, but it regained attention in the 21st century among scholars and practitioners across the globe for several reasons. Pluralistic, multi-actor, and multisectoral governance models gained ground, and the new governance model emphasized collaboration with non-government actors (Kim et al. 2020; Salamon 2003). The global financial crisis in 2008 created fiscal constraints that were somewhat similar to those of the 1970s and 1980s, when the coproduction concept first entered the lexicon of public administration, and a call for a modern version of coproduction for public service provision. Another context generating interest in coproduction is a decline in citizenship and a sense of common self in the community (Nabatchi et al. 2017). In response, practitioners and scholars have sought a new public service model that can reinvigorate the citizen's role beyond that of the customer (Kim et al. 2019; Nabatchi et al. 2017). 
Though coproduction has regained popularity in the public administration field, its emphasis has changed. Some scholars view coproduction as a redefined relationship between government and citizens (service users), while others argue that coproduction creates instrumental value for public organizations by improving effectiveness, innovation, and efficiency (Osborne et al. 2016). Still others emphasize more normative values of coproduction, such as democratic governance, accountability, social capital, and citizenship (Dunston et al. 2009; Meijer 2011). Leadership scholars focus on navigating the changing role of public leaders in coproduction processes (Brown and Head 2019; Harrow and Guest 2020; Kim and Cho 2021). Despite these different approaches, scholars focus on the idea that citizens present untapped resources for public service innovation, which can be mobilized to support a repertoire of institutional arrangements (Alford 2002; Hur et al. 2019; Osborne and Strokosch 2013).

In defining coproduction and developing its typology, scholars consider who is involved and "what/when" they participate in its processes (Nabatchi et al. 2017). The "co-" side of coproduction involves citizen coproducers, such as clients, community members, citizens, and service users volunteering as individuals or as groups, and regular producers, such as government professionals, public agents, and service providers. While this dimension can be expanded to include various actors with voluntary engagements, some scholars specify required relationships for coproduction, such as reciprocal interactions, public value creation, and long-term and active engagement (Nabatchi et al. 2017).

Linders (2012) provided a typology for information and communication technology (ICT)-facilitated coproduction, primarily based on the "co-" side of the concept. The suggested typology offers three categories of coproduction: citizen sourcing (citizen to government, or $\mathrm{C} 2 \mathrm{G}$ ), government as a platform (government to citizen, or $\mathrm{G} 2 \mathrm{C}$ ), and do-it-yourself government (citizen to citizen, or C2C). In citizen sourcing, the government still holds the primary responsibility, while citizens influence direction and improve the government's situational awareness. In government-to-citizen coproduction, the government makes its knowledge and data available to citizens on a public platform but may not take direct responsibility for any resulting activities. This G2C coproduction process may involve a platformization, which refers to the penetration of (governmental or economic) digital platforms into the web and app ecosystems as the dominant infrastructural model (Helmond 2015; Prey 2020; Nieborg and Poell 2018). With the new opportunities of citizen-to-citizen coproduction, citizens self-organize to substitute for the traditional public service delivery model; the government does not play an active role but may offer a facilitating framework.

Nabatchi et al. (2017) developed a coproduction typology based on the phases of its service cycle, focusing on the nature of the production side (broadly defined) or the "what/when" aspect of coproduction. These phases include "co-commissioning," "codesigning," "co-delivery," and "co-assessment" (Nabatchi et al. 2017). Co-commissioning refers to activities that strategically identify what needs to be delivered to whom and to achieve what outcomes. Co-designing focuses on activities that engage user experiences to (re)shape public service arrangements through an outside-in process in order to better understand the services' optimal use. Co-delivery activities are those that lay actors and the government jointly provide or improve, which is most in line with the traditional concept of coproduction. Co-assessment refers to activities associated with evaluating and monitoring public services, in which lay actors and the government work together to assess service quality problems.

\subsection{Citizen-to-Government Communication on Social Media}

Government activities now focus carefully on social media as a central component of e-government or digital transformation initiatives (Bertot et al. 2012; Chen et al. 2020; Ho and Cho 2017). Public agencies employ social media to disseminate information and to communicate with the public (Gruzd et al. 2018). Government use of social media platforms varies in type, depending on the nature of each application, such as microblogging (i.e., 
Twitter), social networking (i.e., Facebook), multimedia sharing (i.e., YouTube), open data (i.e., Data.gov), questioning tools (i.e., Quora), crowdsourcing (i.e., Mechanical Turk), and content syndication (i.e., RSS). It is widely assumed that governments focus on the social media platforms most commonly used, such as Facebook, Twitter, YouTube, and LinkedIn (Oltmann et al. 2020; Wigand 2011); however, the social media technologies used may actually differ according to public agency, jurisdiction, and the frequency of scholarly analysis.

One of the most widely used (by governments) and studied social media platforms is Twitter (Oltmann et al. 2020; Waters and Williams 2011). For example, Alam and Lucas (2011) suggested that Australian public agencies use Twitter to disperse information about government agencies and to report on their activities. Small (2012) found that information provision and service delivery are the main focuses of Canadian government Twitter feeds, although Web 2.0 technologies offer governments numerous other opportunities to engage with citizens. Meijer and Torenvlied (2016) posited that most Twitter communication by the Dutch police is decentralized and used for the purpose of external communication.

In the literature on government use of social media, many studies have explored the intensity of social media use with quantitative indicators, such as the number of retweets, likes, shares, comments, and likes. For example, Bonsón and Ratkai (2013) offered up the social media engagement index, the sum of virality, popularity, and commitment, which has been widely used for measuring citizen engagement. Another significant strand of government social media study explores content type, emotions, and multimedia features (Chen et al. 2020; Im et al. 2014; Rahim et al. 2019; Tang et al. 2021). Previous studies have also identified some key governmental opportunities related to social media platforms, such as democratic engagement, crowdsourcing innovation, and coproduction (Bertot et al. 2012).

\subsection{Social Media and Coproduction}

The advancement of digital technology facilitates new forms of coproduction activities (Meijer 2011). Pestoff (2014) found technology to be an important enabler for greater interaction between government agencies and citizens in coproduction processes. Linders (2012) pointed out that citizen coproduction has transformed in recent years, thanks to the ease of interacting and connecting online, which allows governments and citizens to coordinate actions more effectively. Technology has reduced the cost of information sharing and made social interaction online easier and timelier. Governments and citizens can use the digital infrastructure such as social media at near zero marginal cost for data dissemination or computer-based services.

New digital media creates new connections among geographically dispersed participants that would be impossible with traditional media. The two-way and open nature of social media has also changed the relationship between government and citizens by allowing information sharing and collaboration and encouraging responsiveness and transparency in governance (Bertot et al. 2010; Im et al. 2013; Peixoto and Fox 2016). Digital-media-generated social connections may strengthen the efficiency or effectiveness of public service delivery. Whether or not technology-aided coproduction can fundamentally change how services are provided, digital platforms such as social media can at least offer promising venues for advancing innovative coproduction arrangements.

Research on social media's role in coproducing public service highlights a shift to a more social encounter, as networks of citizens interact with government professionals or public agencies. Resulting citizen-government interactions may lead to couplings of traditionally separated domains (Meijer 2012), as citizens consume factual information while receiving community social support. In this context, social media can create a shared identify or sense of community among different actors, such as lay people and government professionals, an important condition for desired coproduction outcomes.

The real-time nature of social media communications can be quicker, more efficient, and more effective as the bureaucratic nature of government websites may delay response 
times (Mergel 2012). On social media platforms, citizens are better equipped to partner with the government, especially in reporting current public service conditions in their neighborhood or community (Allen et al. 2020; Cho and Ho 2018). Citizens can also monitor government responsiveness and accountability by openly providing real-time feedback on service quality (Allen et al. 2020; Meijer 2014). Panagiotopoulos et al. (2014) suggested that social media has enabled ad hoc conversations among networked participants, both one-toone and many-to-many, which strengthens their abilities to initiate individual or collective actions, such as coproduction. Even without the direct intervention of the government, citizens may self-organize to initiate collective action via social media.

Despite the opportunities for citizen coproduction offered by social media, its benefits are unclear, and adoption may lead to unintended consequences. Empirically, Crump (2011) and Unsworth and Townes (2012) found no clear evidence that the adoption of social media leads to two-way communication and collaboration between government and citizens. Crump (2011) argued that social media does not offer a transformational element to enable engagement and is effective only for disseminating information, and Unsworth and Townes (2012) considered it to be merely a tool to distribute information in the traditional top-down way. Waters and Williams (2011) found that social media does allow engagement between government and citizens but only at a moderate level. Cho and Park (2012) found evidence of reciprocal communication between public agencies and citizens; however, the agency showed a tendency to avoid in-depth dialogue about its policies and activities. Alam and Lucas (2011) studied the use of Twitter in six government agencies in Australia and found that most agencies use social media more for informing or involving citizens rather than consulting or collaborating. Citizens, they continued, show more engagement with the agencies whose functions impact them more regularly and directly. On the other hand, Panagiotopoulos et al. (2014) found that in a contingent emergency situation, Twitter could indeed facilitate meaningful collaboration between government and citizens.

\section{Background: Local Government of Bandung, Indonesia}

In Indonesia, local governments have adopted social media, such as Twitter, as a tool for improving citizen engagement and coproduction in public service delivery. As of 2021, there were 170 million social media users in Indonesia (equivalent to $61.7 \%$ of the total population), generally preferring Facebook, YouTube, Instagram, and Twitter (Kemp 2021). Twitter has attracted 14 million users in Indonesia, which is about $31 \%$ of social media users in the country (Statista 2020). The public reliance on Twitter has extended to municipal governments in Indonesia (Globalwebindex 2015).

In 2013, the Bandung mayor instructed every local government agency to adopt Twitter as a mandatory two-way communication channel between government agencies and citizens (Kishnani 2014), as part of a broader smart city project that looked to reduce the distance between government and citizens and improve collaboration. One goal was to deal with bureaucratic problems in urban services, a department notorious for its belated responses. By using social media as the communication channel, the Bandung municipality hoped to offer citizens more direct access to the government on a real-time basis, as well as an opportunity to contribute to service delivery.

This adoption aligned with the government's recent emphasis on a bottom-up communication strategy to encourage citizens' participation by decentralizing the management and budget to sub-district service units. The public service leaders at the sub-district service unit level are required to meet citizens regularly in order to promote communication and lower the barrier between government and citizens. Direct online and offline interaction is highly encouraged in the current administration, as the mayor expects the municipal government to effectively engage with citizens to coproduce services and improve service quality and accountability.

DBMP Bandung is a sub-district service agency responsible for the municipality's public works, such as maintenance of roads, bridges, street lighting, and drainage systems. 
DBMP Bandung has actively used its social media account, with more than 18,000 Twitter followers and thousands of tweets and retweets each year. This tangible and visible relationship may serve as a testbed for observing coproduction engagement. For example, one of the DBMP Bandung's core responsibilities is to maintain the drainage system, as flooding is a persistent issue in the area; citizen engagement and voluntary participation in coproduction can be effective in this instance (Pratama 2016).

\section{Methods}

This study employed the social media content analysis approach (Schwartz and Ungar 2015; Van Thiel 2014), a quantitative analysis of the words and concepts expressed in social media texts, which has been used extensively across various disciplines. Data-driven content analysis of social media generally does not require the specific a priori theories or theoretical frameworks used to inform many previous studies in the literature. This article's approach is insight-based content analysis (Schwartz and Ungar 2015), which employs exploratory language and image analyses to understand behavioral patterns, as opposed to prediction-focused content analysis, which estimates a specific outcome from words or visual cues. This study uses both the theory-driven categorization method and the theory-free word cluster approach, which still focus on coproduction-related messages in the text.

In studying social-media-aided coproduction, many criteria can assist with case selection, such as deviant case selection, maximum variation cases, and critical case choice. This article selected the case of DBMP Bandung based on the exceptionally heavy traffic and the high number of individual followers of its Twitter account; this somewhat unusual case creates a good context for collecting rich information on various circumstances. Another merit of the DBMP Bandung case is the need to explore coproduction in the context of a developing country, heretofore largely unknown in the literature (Cepiku and Giordano 2014; Ngich and Cho 2020; Sagarik et al. 2018), to identify any limitations of propositions developed in Western democracies.

We harvested tweet data from DBMP Bandung's official Twitter account, including original tweeted text, retweeted (RT) text by the official account, and citizen users' tweets containing a mention (@) of DBMP Bandung. We piloted data collection with a smaller sample to explore emerging themes and codes, which informed our selection of typologies and coding categories, and then collected the main data. Multiple coders assessed and crosschecked the coding results and modified the criteria for rigor in the analysis; in the coding process, the coders used both text information and visual elements of each tweet. This study's unit of analysis was each tweet-unlike some social media content analysis research that uses each word as unit of analysis--because we also analyzed the direction of interactions, such as government-to-citizen or citizen-to-government.

A team of researchers used the open coding method to manually identify different types of messages in relation to coproduction, as well as the theoretically informed coproduction typologies. Since automated data mining would not allow for categorization based on coproduction typologies, researchers coded each tweet and cross-validated for intracoder consistency. Our theoretically informed codes identified the "co-" side of the concept as well as the "production" aspect. On the "co-" side, we used the typology of Linders (2012), with the G2C, C2G, and C2C categories; for the "production" side of the concept, we employed the typology of Nabatchi et al. (2017), or co-commissioning, co-designing, co-delivery, and co-assessment. Open coding produced more in vivo concepts in the tweet data. Examples of tweets coded are presented in Figure 1. 


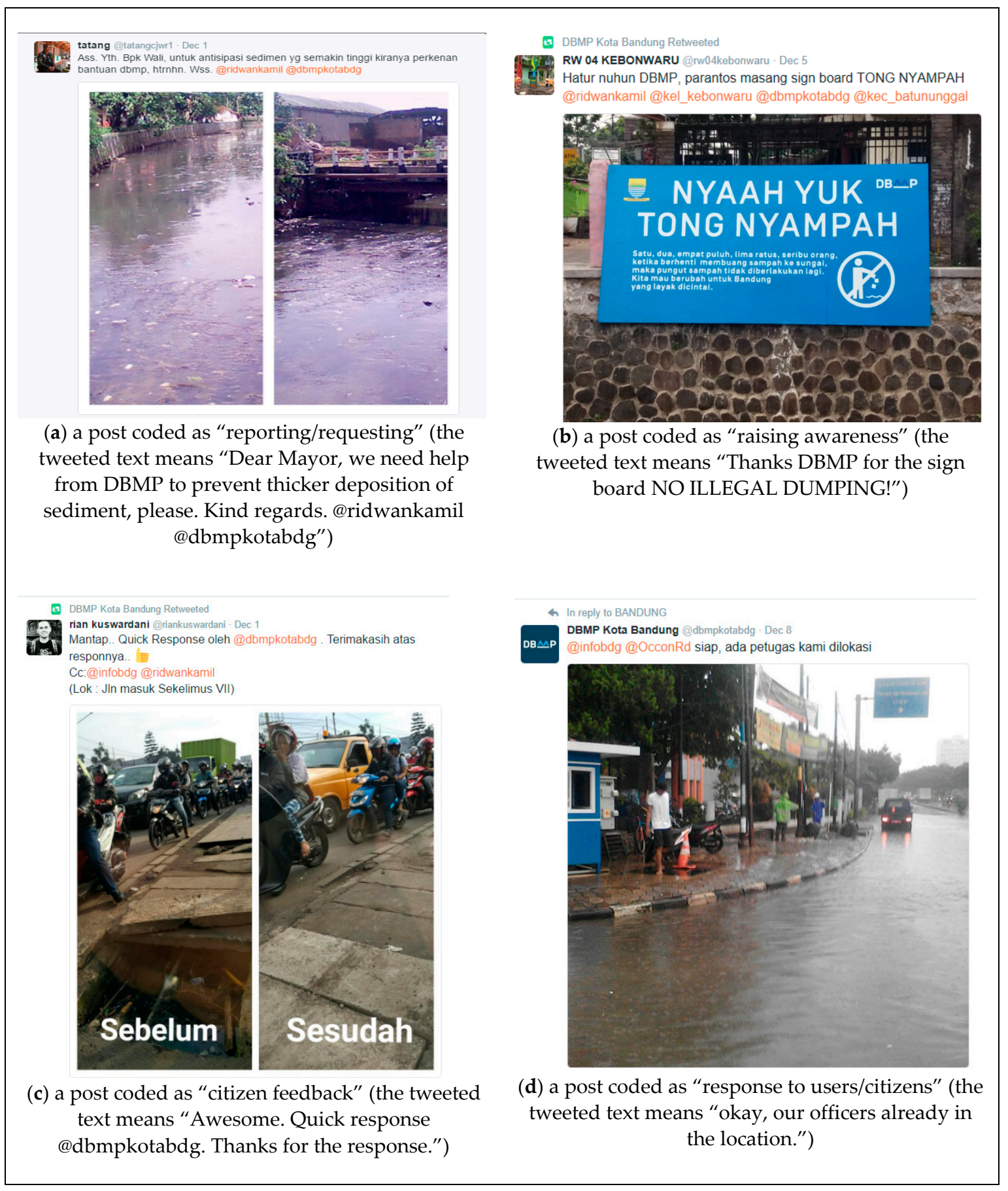

Figure 1. Example of social media posts coded.

\section{Findings}

Figure 2 shows the proportion of social media interaction/communication by coproducer and by coproduction service cycle in the DBMP Bandung data. On the "co-" side of coproduction, we found that social media interactions via DBMP Bandung's official Twitter account are largely driven by government-to-citizen communication, accounting for $86.62 \%$ of the total. An example of these G2C tweets is (with a photo showing staff removing solid waste from the canal) "our cleaning troop is cleaning up the Cinambo Lama canal, Gedebage [translated to English]." This is not surprising; we collected the social media data from the municipal government's sub-district service unit (DBMP Bandung), and their focus is to provide a platform for government messages to citizens regarding coproduction 
activities. While G2C messages may indirectly nudge citizens' voluntary contribution to coproduction, the dominant forms of communication via Twitter are still observed to be messages from the government to citizens. Therefore, we found no clear evidence that the municipal government's social media presence created more two-way interactions.

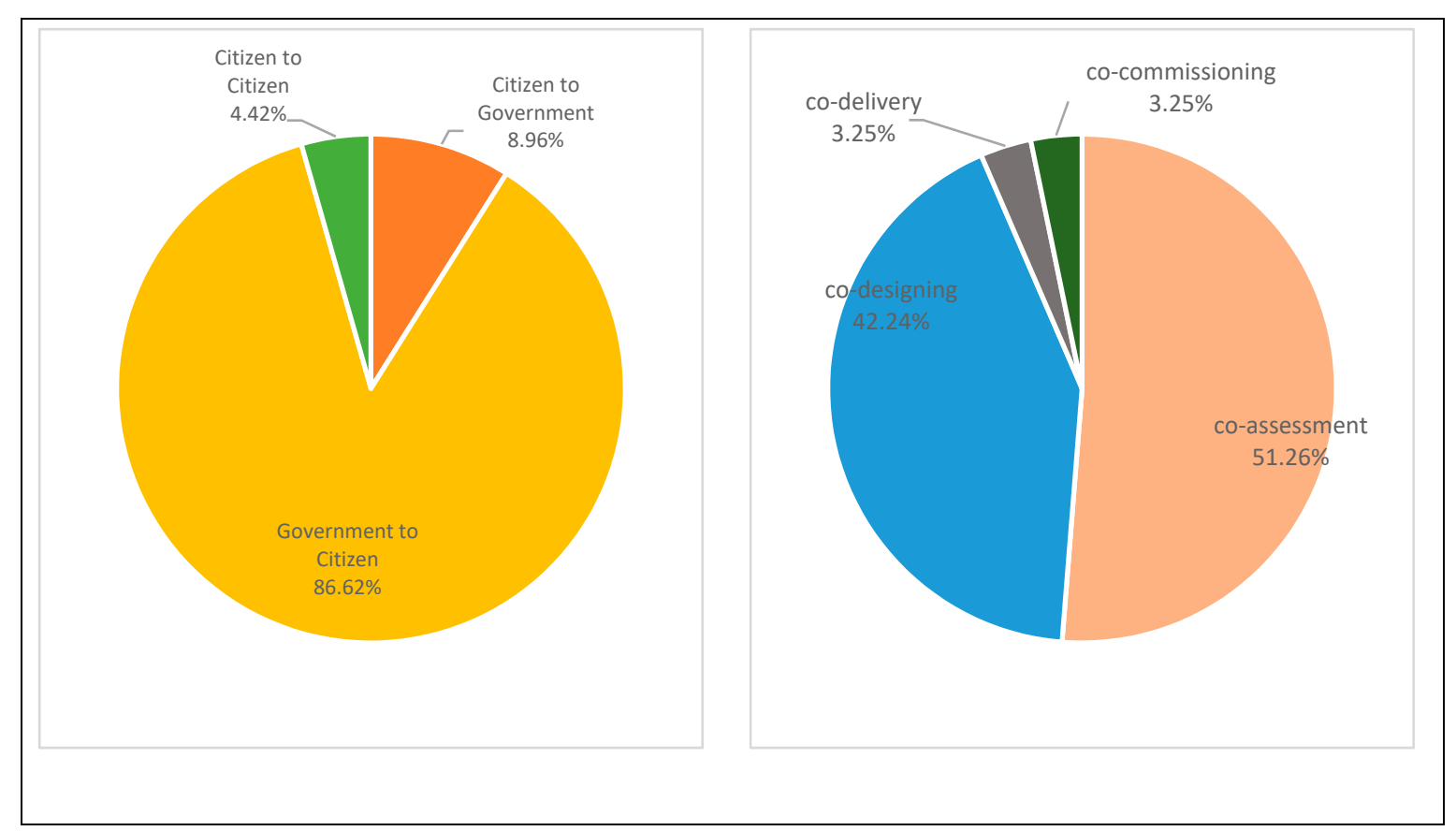

Figure 2. Social media interaction by coproducer and by service cycle.

Citizen-to-government interaction accounted for $8.96 \%$ of all social media interactions regarding DBMP Bandung's coproduction activities-our method only counted the tweets in which DBMP Bandung's official account was mentioned (@) by individual citizen users. An example of tweets coded as $\mathrm{C} 2 \mathrm{G}$ communication is (with a photo showing flooded streets) "Dear Mayor, we need help from DBMP to prevent thicker deposition of sediment please. Kind regards. @ridwankamil @dbmpkotabdg [translated into English]." This relatively small proportion of coproduction-related social media interaction paints a different picture from the rosy prospects described or prescribed by the literature on social-media-facilitated or technology-aided coproduction. This one-sided or one-way digital communication can be seen as a situation in which the municipal government is pining away with an unrequited crush on potential coproduction partners. This may be due to a simple lack of awareness about municipal government activities or the citizens' unwillingness to express themselves on social media due to concerns over privacy or lack of efficacy. However, this low level of citizen-to-government communication can be interpreted more positively if we consider the communication barriers experienced by citizen users or coproducers.

The proportion of citizen-to-citizen interactions, $4.42 \%$ of coproduction-related tweets mentioning DBMP Bandung, may be under-estimated in our data; we did not count how many individual citizen users may have retweeted just to pass information along, rather than directly communicating with audiences or endorsing it. Our methodology may also under-estimate the occurrence of actual coproduction activities as citizen-to-citizen interactions. Despite this, however, we can still suggest that there was no clear evidence that the social media presence of the municipal government facilitates active and widespread two-way communication between government and citizens or between different citizen actors.

Regarding the coproduction service cycle, we found that $51.26 \%$ of the social media interactions relate to co-assessment and $42.24 \%$ are about co-designing. Therefore, our 
observations show that the dominant forms of coproduction communications in DBMP Bandung's Twitter account are co-assessment and co-designing. Co-assessment may be past oriented, or retrospective, while co-designing is generally future oriented, or prospective. Notably, retrospective communication is the most dominant coproduction communication, followed by prospective: this is unsurprising, since the results of co-assessment activities may be used prospectively to reshape the service process. Co-delivery and cocommissioning each took up $3.25 \%$ of the social media interaction, insignificant proportions of the total Twitter communications.

Table 1 shows the identified categories of coproduction communications. Our researchers conducted open coding of tweets to better ground the emerging coproduction communications categories in the collected social media text data. From our open coding, emerged codes were summarized and cleaned into eight categories: "informing or dissemination," "raising awareness," "reporting or requesting," "citizen feedback," "citizen consultation," and "respond to users or citizens." The "informing or dissemination" category refers to codes associated with updates of government or citizen (coproduction) activities. "Raising awareness" is the category of codes on nudging or promoting certain citizen behaviors for coproduction. The "reporting or requesting" category refers to the codes that represent reporting problems or asking for a certain service or information-examples of tweets coded as "reporting or requesting" include (with a photo showing the traffic jam) @dbmpkotabdg "How is the condition at Gedebage intersection now? [translated into English]." The "citizen feedback" category was derived from codes about appreciation or complaints related to government/citizen actions. "Citizen consultation" refers to the codes associated with social media initiatives by citizens that support government activities or service delivery. The category of "respond to users or citizens" refers to codes related to DBMP Bandung responses to individual citizen requests or questions on social media.

Table 1. Definitions of categories (results of open coding).

\begin{tabular}{ll}
\hline \multicolumn{1}{c}{ Categories } & \multicolumn{1}{c}{ Definition } \\
\hline Informing/dissemination & Updates of government or citizen (coproduction) activities \\
Raising awareness & Nudging or promoting certain citizen behaviors for coproduction \\
Reporting/requesting & Reporting problems or asking for a certain service or information \\
Appreciating actions done by the government/citizens or & complaining about them \\
Citizen feedback & Initiatives by citizens that support government activities or \\
Respond to users/citizens & service delivery \\
& Response to individual citizens' requests or questions
\end{tabular}

We found that "informing or dissemination" (46.42\%) is the most commonly observed category of communication in social-media-enabled coproduction in DBMP Bandung. Within this category, we observed that various visual tools are used in conveying the municipal government's messages on the social media platform. As shown in Figure 3, "raising awareness" accounted for 42.24\% of the tweets on DBMP Bandung's Twitter account; this category and "informing or dissemination" make up over $90 \%$ of interactions regarding coproduction. "Citizen feedback" was observed to account for $4.84 \%$ of the social media interaction on coproduction, and "reporting or requesting" accounted for $3.45 \%$. "Citizen consultation" was observed to account for $2.06 \%$, while "respond to user or citizen" accounted for only $0.99 \%$. 


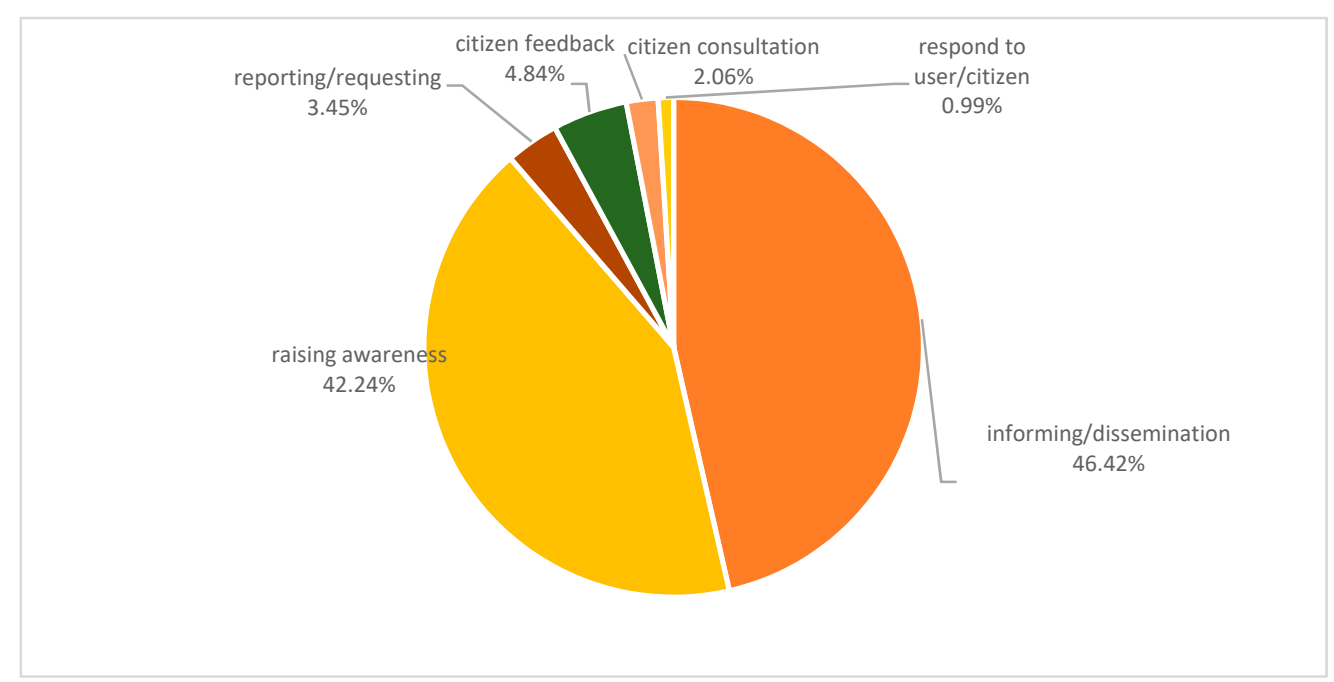

Figure 3. Categories of interaction identified in the DBMP Twitter account.

\section{Discussion}

The results of our social media content analysis provided several insights into the manner in which DBMP Bandung uses Twitter to pursue coproduction of services. They reveal an emphasis on the visibility of coproduction activities and raising citizen awareness to encourage voluntary participation. Our findings show dominantly government-tocitizen communications via informing or dissemination; this is consistent with Small (2012), who found that the government continues to treat citizens as passive recipients of information and services. Though the expected two-way interactions were not widely observed by this study, the importance of sharing coproduction knowledge with citizens via social media remains a vital concern. Studies show that citizens are more likely to coproduce when they understand why their input matters and how to participate in coproduction (Jakobsen and Andersen 2013). Informing and disseminating successful examples of coproduction may also be associated with the self-efficacy perception of citizens' influence on coproduction, which, in turn, fosters their active, persistent involvement (Thomsen 2017).

DBMP Bandung's lack of available financial resources provides an important context for the need to solicit citizen participation in coproduction via social media. In many urban municipal government departments, providers need cooperation from citizens; the level of citizen compliance with urban policies can be a decisive factor in the efficient use of budgets and the effectiveness of service delivery. For instance, illegal dumping has been an ongoing issue for DBMP Bandung. In addition to general environmental damage and hazards, dumping has caused removal costs to rise as well as costly long-term effects from flooding, as solid waste blocks existing drainage channels, which worsens during rain. DBMP Bandung sees social-media-aided citizen coproduction as a cost-free or cost-effective tool for developing citizens' sense of community ownership, which contributes to lowregret solid waste and flood risk management programs. If DBMP Bandung's social media communication and engagement can foster voluntary actions of citizens in, for instance, reporting or removing illegal dumping, it could significantly lower direct and indirect costs for the municipal sub-district service unit.

In contrast, Marwick and Boyd (2011) suggested that Twitter's nature makes it nearly impossible to assess the extent to which a tweet can reach different audiences. Hence, it is not easy to judge the genuine effectiveness of DBMP Bandung's Twitter account, despite its high traffic in comparison to its government peers (Gandapurnama 2015). For example, the DBMP Bandung account has more than 18,000 official followers. While this number seems large, there are 2 million residents in the Bandung municipality (Data Bandung 2016). Therefore, its reach to the general public may be less than robust. A huge number 
of citizens do not use social media or follow DBMP's Twitter account, so the findings of our analysis may only show an incomplete picture of government-citizen interaction. However, the phenomenon of social-media-enabled coproduction is still young, and these early observations may suggest the potential for a deep impact of technology and new media on the coproduction of public services.

In DBMP Bandung, social media was used, not in isolation, but as part of a more holistic strategy by the service agency and the municipal government. For example, DBMP Bandung often tweeted about its campaign to reduce illegal dumping of waste items, such as furniture, mattresses, tires, and household rubbish, in order to raise awareness about its impact on flooding and solicit citizen help in alleviating the problem. By using Twitter, DBMP Bandung seemed to attempt to nudge the mind-set of citizens toward their roles as co-producers of services rather than passive consumers. Since monetary or extrinsic rewards may not be effective in stimulating coproduction (Kim and Cho 2014; Voorberg et al. 2018), this nudging approach can be a useful tool for municipal governments to encourage citizens to volunteer and to stimulate their coproduction interests.

\section{Conclusions}

This study investigated a municipal government's use of social media for citizen coproduction in public works service delivery by examining its adoption and use of the platform Twitter. To better understand the context, we conducted a social media content analysis of a collection of tweets from DBMP Bandung's Twitter account and evaluated the interactions found within. This article explored an under-studied context of a developing country's social-media-aided coproduction, contributing to a better understanding of the phenomenon in a non-Western context. Since social media research has been conducted in the context of Western democracies, Asian and Southeast Asian countries have been under-represented in the body of knowledge in this field (Wen et al. 2021).

Our research questions were 'What types of citizen coproduction are observed in a municipal government's social media platform?' and 'To what extent does the adoption of Twitter leverage two-way communication between government and citizens regarding citizen coproduction with municipal government?' In regard to the types of coproduction, the majority of the social media communications were found to be related to co-assessment and co-designing, with a limited number of tweets about co-delivery or co-commissioning. As to the extent to which the social media leverages two-way communication, our findings suggest that the dominant form of social media interaction regarding citizen coproduction is government-to-citizen (G2C) interaction, focused primarily on informing and nudging for citizen coproduction, while there are only limited elements of citizen-to-government (C2G) communication, such as citizen sourcing and citizen reporting.

This study, however, had limitations that future research should address. Our social media data analysis did not use automated procedures in identifying latent themes or topics due to our focus on the unit of analysis (an individual tweet). In addition, our method is not free from reliability and subjectivity issues in manual coding; a future study can address this issue by employing a more objective method, such as Latent Dirichlet allocation modeling, although this modeling may exhibit its own limitation. As this research was exploratory by nature, we did not test any causal relationships. We suggest the need for future studies on relationships, such as how different types of social media communication affect coproduction outcomes or how social media engagement changes the coproduction processes. Finally, our findings, specific to a municipal government's service unit in Indonesia, may not be generalizable to a wider context. Future research should collect data from multiple representative jurisdictions to identify more generalizable empirical evidence.

Author Contributions: Conceptualization, W.C. and W.D.M.; methodology, W.C.; validation, W.C. and W.D.M.; formal analysis, W.C. and W.D.M.; re-sources, W.C.; writing-original draft preparation, W.D.M.; writing—review and editing, W.C.; visualization, W.C.; supervision, W.C.; project adminis- 
tration, W.C.; funding acquisition, W.C. All authors have read and agreed to the published version of the manuscript.

Funding: This research was partially funded by National Research Foundation of Korea, grant number NRF-2017S1A3A2065838, and partially by WSBG Research Support Grant, grant number 4197-226486.

Institutional Review Board Statement: Not applicable.

Informed Consent Statement: Not applicable.

Data Availability Statement: The data is available upon request.

Conflicts of Interest: The authors declare no conflict of interest.

\section{References}

Alam, Sultana Lubna. 2020. Many hands make light work: Towards a framework of digital co-production to co-creation on social platforms. Information Technology and People 34: 1087-118. [CrossRef]

Alam, Lubna, and Richard Lucas. 2011. Tweeting government: A case of Australian government use of Twitter. Paper presented at the Dependable, Autonomic and Secure Computing (DASC), 2011 IEEE Ninth International Conference, Sydney, Australia, December 12-14; pp. 995-1001.

Alford, John. 2002. Defining the client in the public sector: A social-exchange perspective. Public Administration Review 62: 337-46. [CrossRef]

Allen, Barbara, Louise E. Tamindael, Sarah H. Bickerton, and Wonhyuk Cho. 2020. Does citizen coproduction lead to better urban services in smart cities projects? An empirical study on e-participation in a mobile big data platform. Government Information Quarterly 37: 101412. [CrossRef]

Andersen, Simon Calmar, Helena Skyt Nielsen, and Mette Kjærgaard Thomsen. 2020. How to increase citizen coproduction: Replication and extension of existing research. International Public Management Journal 23: 696-712. [CrossRef]

Bertot, John C., Paul T. Jaeger, and Justin M. Grimes. 2010. Using ICTs to create a culture of transparency: E-government and social media as openness and anti-corruption tools for societies. Government Information Quarterly 27: 264-71. [CrossRef]

Bertot, John Carlo, Paul T. Jaeger, and Derek Hansen. 2012. The impact of polices on government social media usage: Issues, challenges, and recommendations. Government Information Quarterly 29: 30-40. [CrossRef]

Bonsón, Enrique, and Melinda Ratkai. 2013. A set of metrics to assess stakeholder engagement and social legitimacy on a corporate Facebook page. Online Information Review 37: 787-803. [CrossRef]

Bovaird, Tony. 2007. Beyond engagement and participation: User and community coproduction of public services. Public Administration Review 67: 846-60. [CrossRef]

Brown, Prudence R., and Brian W. Head. 2019. Navigating tensions in co-production: A missing link in leadership for public value. Public Administration 97: 250-63. [CrossRef]

Brudney, Jeffrey L., and Robert E. England. 1983. Toward a definition of the coproduction concept. Public Administration Review 43: 59-65. [CrossRef]

Cepiku, Denita, and Filippo Giordano. 2014. Co-Production in Developing Countries: Insights from the community health workers experience. Public Management Review 16: 317-40. [CrossRef]

Chen, Qiang, Chen Min, Wei Zhang, Ge Wang, Xiaoyue Ma, and Richard Evans. 2020. Unpacking the black box: How to promote citizen engagement through government social media during the COVID-19 crisis. Computers in Human Behavior 110: 106380. [CrossRef]

Cho, Wonhyuk, and Alfred Tat-Kei Ho. 2018. Does neighborhood crime matter? A multi-year survey study on perceptions of race, victimization, and public safety. International Journal of Law, Crime and Justice 55: 13-26. [CrossRef]

Cho, Seong Eun, and Han Woo Park. 2012. Government organizations' innovative use of the Internet: The case of the Twitter activity of South Korea's Ministry for Food, Agriculture, Forestry and Fisheries. Scientometrics 90: 9-23. [CrossRef]

Crump, Jeremy. 2011. What are the police doing on Twitter? Social media, the police and the public. Policy and Internet 3: 1-27. [CrossRef]

Daneshvar, Hadi, Stuart Anderson, Robin Williams, and Hajar Mozaffar. 2018. How can social media lead to co-production (co-delivery) of new services for the elderly population? A qualitative study. JMIR Human Factors 5: e5. [CrossRef] [PubMed]

Data Bandung. 2016. Jumlah Penduduk Berdasarkan Jenis Kelamin Tahun. Portal Data Kota Bandung.

Dipoppa, Gemma, and Guy Grossman. 2020. The effect of election proximity on government responsiveness and citizens' participation: Evidence from English local elections. Comparative Political Studies 53: 2183-212. [CrossRef]

Dunston, Roger, Alison Lee, David Boud, Pat Brodie, and Mary Chiarella. 2009. Co-production and health system reform-from re-imagining to re-making. Australian Journal of Public Administration 68: 39-52. [CrossRef]

Edelmann, Noella, and Ines Mergel. 2021. Co-production of digital public services in Austrian public administrations. Administrative Sciences 11: 22. [CrossRef] 
Fotaki, Marianna. 2011. Towards developing new partnerships in public services: Users as consumers, citizens and/or co-producers in health and social care in England and Sweden. Public Administration 89: 933-55. [CrossRef] [PubMed]

Gandapurnama, Baban. 2015. Kisah Admin Medsos Pengawal Pasukan 'Katak' dan Penakluk Api. DetikNews. Available online: https:// news.detik.com/berita/d-2955091/kisah-admin-medsos-pengawal-pasukan-katak-dan-penakluk-api?utm_source= copy_url\&utm_campaign=detikcomsocmed\&utm_medium=btn\&utm_content=news (accessed on 1 June 2021).

Gazley, Beth, Chantalle LaFontant, and Yuan Cheng. 2020. Does coproduction of public services support government's social equity goals? The case of U.S. state parks. Public Administration Review 107: 504. [CrossRef]

Globalwebindex. 2015. Globalwebindex's Quarterly Report on the Latest Trends in Social Networking. London: Globalwebindex.

Gruzd, Anatoliy, James Lannigan, and Kevin Quigley. 2018. Examining government cross-platform engagement in social media: Instagram vs. Twitter and the big lift project. Government Information Quarterly 35: 579-87. [CrossRef]

Harrow, Jenny, and Matthew Guest. 2020. New development: Institutions, 'new civic leadership' and being 'truly civic': Some tensions in co-production debates. Public Money and Management, 1-5. [CrossRef]

Helmond, Anne. 2015. The platformization of the web: Making web data platform ready. Social Media+ Society 1: 2056305115603080. [CrossRef]

Ho, Alfred Tat-Kei, and Wonhyuk Cho. 2017. Government communication effectiveness and satisfaction with police performance: A large-scale survey study. Public Administration Review 77: 228-39. [CrossRef]

Hong, Sounman. 2016. Representative bureaucracy, organizational integrity, and citizen coproduction: Does an increase in police ethnic representativeness reduce crime? Journal of Policy Analysis and Management 35: 11-33. [CrossRef]

Hur, Joon-Young, Wonhyuk Cho, Geon Lee, and Sarah Hendrica Bickerton. 2019. The "smart work" myth: How bureaucratic inertia and workplace culture stymied digital transformation in the relocation of South Korea's capital. Asian Studies Review 43: 691-709. [CrossRef]

Im, Tobin, Hyunkuk Lee, Wonhyuk Cho, and Jesse W. Campbell. 2013. Citizen preference and resource allocation: The case for participatory budgeting in Seoul. Local Government Studies 40: 102-20. [CrossRef]

Im, Tobin, Wonhyuk Cho, Greg Porumbescu, and Jungho Park. 2014. Internet, trust in government, and citizen compliance. Journal of Public Administration Research and Theory 24: 741-63. [CrossRef]

Jakobsen, Morten, and Simon Calmar Andersen. 2013. Coproduction and equity in public service delivery. Public Administration Review 73: 704-13. [CrossRef]

Joshi, Anuradha, and Mick Moore. 2004. Institutionalised co-production: Unorthodox public service delivery in challenging environments. Journal of Development Studies 40: 31-49. [CrossRef]

Kang, Sinah, and Gregg G. Van Ryzin. 2019. Coproduction and trust in government: Evidence from survey experiments. Public Management Review 21: 1646-64. [CrossRef]

Kemp, S. 2021. Digital 2021: Indonesia. DataReportal. Available online: https://datareportal.com/reports/digital-2021-indonesia (accessed on 1 June 2021).

Kiewiet, D. Roderick, and Mathew D. McCubbins. 2014. State and local government finance: The new fiscal ice age. Annual Review of Political Science 17: 105-122. [CrossRef]

Kim, Nanyoung, and Wonhyuk Cho. 2014. Agencification and performance: The impact of autonomy and result-control on the performance of executive agencies in Korea. Public Performance \& Management Review 38: 214-33. [CrossRef]

Kim, Taeyeon, and Wonhyuk Cho. 2021. Leadership effect on performance of quasi-governmental organizations: Substituting and neutralizing role of HRM practices and employee-friendly policies. Korean Journal of Public Administration 30: 47-80. [CrossRef]

Kim, Daewook, Wonhyuk Cho, and Hae-Yug Park. 2019. Asset-building approaches to community development and the role of local government in urban regeneration. The Korean Journal of Public Administration 28: 85-119.

Kim, Daewook, Wonhyuk Cho, and Barbara Allen. 2020. Sustainability of social economy organizations (SEOs): An analysis of the conditions for surviving and thriving. The Social Science Journal, 1-17. [CrossRef]

Kishnani, N. 2014. The FuturArc Interview Ridwan Kamil Mayor, City of Bandung. FuturArc. Available online: https:/ / www.futurarc. com/index.cfm/editorial/futurarc-interview/ (accessed on 1 June 2021).

Linders, Dennis. 2012. From e-government to we-government: Defining a typology for citizen coproduction in the age of social media. Government Information Quarterly 29: 446-54. [CrossRef]

Liu, Helen K. 2021. Crowdsourcing: Citizens as coproducers of public services. Policy and Internet. [CrossRef]

Marwick, Alice E., and Danah Boyd. 2011. I tweet honestly, I tweet passionately: Twitter users, context collapse, and the imagined audience. New Media and Society 13: 114-33. [CrossRef]

Mattson, Gary A. 1986. The promise of citizen coproduction: Some persistent issues. Public Productivity Review 10: 51. [CrossRef]

McGann, Michael, Tamas Wells, and Emma Blomkamp. 2021. Innovation labs and co-production in public problem solving. Public Management Review 23: 297-316. [CrossRef]

McMullin, Caitlin. 2021. Challenging the necessity of New Public Governance: Co-production by third sector organizations under different models of public management. Public Administration 99: 5-22. [CrossRef]

Meijer, Albert Jacob. 2011. Networked coproduction of public services in virtual communities: From a government-centric to a community approach to public service support. Public Administration Review 71: 598. [CrossRef]

Meijer, Albert. 2012. Co-production in an information Age: Individual and community engagement supported by new media. Voluntas: International Journal of Voluntary and Nonprofit Organizations 23: 1156-72. [CrossRef] 
Meijer, Albert Jacob. 2014. New media and the coproduction of safety. The American Review of Public Administration 44: 17-34. [CrossRef] Meijer, Albert Jacob, and René Torenvlied. 2016. Social media and the new organization of government communications: An empirical analysis of Twitter usage by the Dutch police. The American Review of Public Administration 46: 143-61. [CrossRef]

Mergel, Ines. 2012. Social Media in the Public Sector: A Guide to Participation, Collaboration and Transparency in the Networked World. Hoboken: John Wiley and Sons.

Nabatchi, Tina, Alessandro Sancino, and Mariafrancesca Sicilia. 2017. Varieties of participation in public services: The who, when, and what of coproduction. Public Administration Review 77: 766-776. [CrossRef]

Ngich, Lor, and Wonhyuk Cho. 2020. Addressing police corruption in Southeast Asia: Politics, participation, and public management reform. Public Administration Issues 5: 9-34. [CrossRef]

Nieborg, David B., and Thomas Poell. 2018. The platformization of cultural production: Theorizing the contingent cultural commodity. New Media and Society 20: 4275-92. [CrossRef]

Oltmann, Shannon M., Troy B. Cooper, and Nicholas Proferes. 2020. How Twitter's affordances empower dissent and information dissemination: An exploratory study of the rogue and alt government agency Twitter accounts. Government Information Quarterly 37: 101475. [CrossRef]

Osborne, Stephen P., and Kirsty Strokosch. 2013. It takes two to tango? Understanding the co-production of public services by integrating the services management and public administration perspectives. British Journal of Management 24: S31-S47. [CrossRef]

Osborne, Stephen P., Zoe Radnor, and Kirsty Strokosch. 2016. Co-production and the co-creation of value in public services: A suitable case for treatment? Public Management Review 18: 639-53. [CrossRef]

Ostrom, Elinor. 1996. Crossing the great divide: Coproduction, synergy, and development. World Development 24: 1073-87. [CrossRef]

Panagiotopoulos, Panagiotis, Alinaghi Ziaee Bigdeli, and Steven Sams. 2014. Citizen-government collaboration on social media: The case of Twitter in the 2011 riots in England. Government Information Quarterly 31: 349-57. [CrossRef]

Parks, Roger B., Paula C. Baker, Larry Kiser, Ronald Oakerson, Elinor Ostrom, Vincent Ostrom, Stephen L. Percy, Martha B. Vandivort, Gordon P. Whitaker, and Rick Wilson. 1981. Consumers as coproducers of public services: Some economic and institutional considerations. Policy Studies Journal 9: 1001-11. [CrossRef]

Peixoto, Tiago, and Jonathan Fox. 2016. When does ICT-enabled citizen voice lead to government responsiveness? IDS Bulletin 47: 23-40. [CrossRef]

Pestoff, Victor. 2006. Citizens and co-production of welfare services. Public Management Review 8: 503-19. [CrossRef]

Pestoff, Victor. 2014. Collective action and the sustainability of co-production. Public Management Review 16: 383-401. [CrossRef]

Pratama, Fajar. 2016. Catatan Bnpb Soal Banjir Bandung: Dari Tumpukan Sampah Sampai Perlunya Bpbd. DetikNews. Available online: https: //news.detik.com/berita/d-3328313/catatan-bnpb-soal-banjir-bandung-dari-tumpukan-sampah-sampai-perlunya-bpbd (accessed on 1 June 2021).

Prey, Robert. 2020. Locating power in platformization: Music streaming playlists and curatorial power. Social Media + Society 6: 2056305120933291. [CrossRef]

Rahim, Afiq Izzudin, Mohd Ismail Ibrahim, Faizul Nizam A. Salim, and Mohd Ariff Ikram Ariffin. 2019. Health information engagement factors in Malaysia: A content analysis of Facebook use by the Ministry of Health in 2016 and 2017. International Journal of Environmental Research and Public Health 16: 591. [CrossRef]

Sagarik, Danuvas, Pananda Chansukree, Wonhyuk Cho, and Evan Berman. 2018. E-government 4.0 in Thailand: The role of central agencies. Information Polity 23: 343-53. [CrossRef]

Salamon, Lester M. 2003. The Resilient Sector: The State of Nonprofit America. Washington, DC: Brookings Institution Press.

Schwartz, H. Andrew, and Lyle H. Ungar. 2015. Data-driven content analysis of social media: A systematic overview of automated methods. The ANNALS of the American Academy of Political and Social Science 659: 78-94. [CrossRef]

Sievert, Martin. 2021. A replication of "representative bureaucracy and the willingness to coproduce". Public Administration. [CrossRef]

Small, Tamara A. 2012. E-Government in the age of social media: An analysis of the Canadian government's use of Twitter. Policy and Internet 4: 91-111. [CrossRef]

Statista. 2020. Social Media Platforms Used Every Day Indonesia. Available online: https://www.statista.com/statistics/1168819/ indonesia-social-media-platforms-used-daily / (accessed on 1 June 2021).

Tang, Zhenya, Andrew S. Miller, Zhongyun Zhou, and Merrill Warkentin. 2021. Does government social media promote users' information security behavior towards COVID-19 scams? Cultivation effects and protective motivations. Government Information Quarterly 38: 101572. [CrossRef]

Thomsen, Mette Kjærgaard. 2017. Citizen coproduction: The influence of self-efficacy perception and knowledge of how to coproduce. American Review of Public Administration 47: 340-53. [CrossRef]

Thomsen, Mette Kjærgaard, Martin Baekgaard, and Ulrich Thy Jensen. 2020. The psychological costs of citizen coproduction. Journal of Public Administration Research and Theory 30: 656-73. [CrossRef]

Unsworth, Kristene, and Adam Townes. 2012. Social media and E-Government: A case study assessing Twitter use in the implementation of the open government directive. Proceedings of the American Society for Information Science and Technology 49: 1-3. [CrossRef]

Van Thiel, Sandra. 2014. Research Methods in Public Administration and Public Management: An Introduction. Abingdon: Routledge.

Venugopalan, Murale, Bettina Lynda Bastian, and P. K. Viswanathan. 2021. The role of multi-actor engagement for women's empowerment and entrepreneurship in Kerala, India. Administrative Sciences 11: 31. [CrossRef] 
Voorberg, William, Sebastian Jilke, Lars Tummers, and Victor Bekkers. 2018. Financial rewards do not stimulate coproduction: Evidence from two experiments. Public Administration Review 78: 864-73. [CrossRef]

Waters, Richard D., and Jensen M. Williams. 2011. Squawking, tweeting, cooing, and hooting: Analyzing the communication patterns of government agencies on Twitter. Journal of Public Affairs 11: 353-63. [CrossRef]

Wen, Deng, Wonhyuk Cho, Jia-Huey Hsu, and Karl Lofgren. 2021. Who is leading China's family planning policy discourse in Weibo? Policy and Internet.

Whitaker, Gordon P. 1980. Coproduction: Citizen participation in service delivery. Public Administration Review 40: 240-46. [CrossRef]

Wigand, F. Dianne Luxa. 2011. Tweets and retweets: Twitter takes wing in government. Information Polity 16: 215-24. [CrossRef] 